\title{
Juridical Review of The Complete Systematic Land Registration in Indonesia
}

\author{
Vincentius Hari Supriyanto ${ }^{1}$, Damianus Krismantoro ${ }^{2}$ \\ ${ }^{1,2}$ Lecturer at the Faculty of Law, Atma Jaya University, Yogyakarta, Indonesia \\ E-mail: hari.supriyanto@uajy.ac.id.
}

\begin{abstract}
The Complete Systematic Land Registration (PTSL) activity is a Government program to achieve legal certainty and the existence of a single map in Indonesia. Therefore, the target of PTSL is land that does not have a certificate in one village. Prior to the PTSL activity, there was an activity called the National Agrarian Operation Project (PRONA). These activities were not successful, so there was a new land registration system called PTSL. The methods used in this research are normative and empirical juridical methods. The results of a study on the implementation of Complete Systematic Land Registration (PTSL) in Indonesia show that it has provided legal certainty to land owners. However, in implementing PTSL in Indonesia, there are still obstacles in the implementation of PTSL. These obstacles include the lack of adequate human resources to support the implementation of PTSL, the lack of facilities and infrastructure for implementing PTSL in the regions, the lack of full support from the community for PTSL activities, and the large tax costs on land owned by the community.
\end{abstract}

Keywords: juridical review, complete systematic registration, legal certainty

DOI: $10.7176 / \mathrm{JLPG} / 101-18$

Publication date:September $30^{\text {th }} 2020$

\section{Introduction}

Land registration is a series of activities carried out by the State / Government continuously and regularly, in the form of collecting certain information or data regarding certain lands in certain areas. In this land registration, there is also a process of processing, storing, and presenting data for the benefit of the people, in order to guarantee legal certainty in the land sector, including the issuance of evidence and its maintenance (Harsono, 2003). Land registration activities in Indonesia as stipulated in Government Regulation (PP) Number 24 of 1997 concerning Land Registration consist of first-time land registration and data maintenance. First-time land registration activities can be carried out sporadically or systematically. PP No. 24 of 1997 as a substitute for PP. 10 of 1961 concerning Land Registration is intended to implement the provisions contained in Article 19 of Law Number 5 of 1960 concerning the Basic Agrarian Law (UUPA) which states that land registration is carried out in all parts of Indonesia. Sporadic land registration is the activity of registering land for the first time regarding one or several objects of land registration in the territory or territory of a village individually or in bulk. Sporadic land registration is carried out at the request of interested parties (Sangsun, 2007).

The first-time land registration through 'sporadic' means that the registration of the land is carried out by a group of people who will register land that still has old title status. Meanwhile, the first-time land registration through 'systematic' is the first land registration carried out by the Government of a village whose land still does not have a land certificate. The administration of land registration is carried out by the Government, and in this case the organizing agency is the Office of the National Land Agency (BPN) in the Land Registration Section, which exists in every Regency or City (Tehupeiory, 2012).

The first land registration activity was the National Agrarian Operation Project (PRONA) which was implemented since 1981 based on the Minister of Home Affairs Decree Number 189 of 1981 concerning the National Agrarian Operation Project. The purpose of PRONA is to implement the State Policy Guidelines (GBHN) and regulations in the land sector, particularly in granting certificates to people who do not have them. The weakness of the PRONA program that was rolled out from 1981 to 2016 is that it has not been able to certify all land in Indonesia until it changed to Complete Systematic Land Registration in 2016. Prona has only succeeded in certifying land as much as $44 \%$ of the total land in Indonesia, so that $56 \%$ of the land is still not yet certified in Indonesia (Ihsanuddin, 2020).

This Complete Systematic Land Registration (PTSL) is the first land registration activity, which is carried out simultaneously for all land registration objects throughout the Republic of Indonesia in one village area or other area at the same level as a village. PTSL includes collecting and determining the correctness of physical data and juridical data regarding one or more land registration objects for registration purposes.

During 2018, the Ministry of Agrarian Affairs and Spatial Planning / Head of the National Land Agency (ATR / 
BPN) issued 9.4 million certificates in the Complete Systematic Land Registration (PTSL) program or popularly known as the free certificate sharing program (Kominfo,go.id., 2019). Minister of ATR / BPN, Sofyan Djalil explained that during 2018, ATR / BPN initially had a target of 7.5 million certificates to be completed. The priority areas of this program are areas prone to land conflicts and densely populated, such as Java Island. Sofyan explained, the target for 2019 is still at 9 million certificates. The Complete Systematic Land Registration Program (PTSL) is one of the flagship programs of the Indonesian government under President Joko Widodo. With this PTSL program, it is hoped that all land plots in Indonesia can be registered and certified immediately. In addition to legal certainty, the certified land plot information can also be used as an instrument for policy making and investment. The background of implementing the PTSL program is that the Government is still discovering land in Indonesia that is not yet certified or not. Land certificates are strong evidence of community ownership of land. The government does not charge the community for the land registration process, but only charges administrative costs, such as the provision of land certificates for land that do not have land certificates, making and installing boundary marks, transitional taxes, stamp duty fees, photocopies of land ownership certificates such as letter C, or witness fees (Ayu, 2019).

The ATR / BPN Ministry, which targets 126 million land plots in Indonesia to be registered and certified by 2025. This is then elaborated into the targets of 5 million plots in 2017, 7 million plots in 2018, 9 million plots in 2019 and 10 million annually until 2025. If land registration in Indonesia is carried out with a routine as usual, where a year can only be approximately 500 thousand plots, it will take 160 years to register land throughout Indonesia (Purbaya, 2017).

Based on the description above, several problems can be raised as follows: First, how to systematically regulate land registration in Indonesia; Second, what are the obstacles in implementing the systematic land registration activities.

\section{Research Method}

This type of research is normative legal research, also known as doctrinal legal research or secondary data research. Secondary data sources are data obtained from literature reviews, statutory regulations, literature books, which consist of:

a. Primary legal materials consist of: Law Number 5 of 1960 concerning Basic Agrarian Principles, Government Regulation Number 10 of 1961 concerning Land Registration, Government Regulation Number 24 of 1997 concerning Land Registration, Presidential Instruction Number 2 of 2018 concerning Acceleration of Registration Complete Systematic Land throughout the Territories of the Republic of Indonesia, Regulation of the Minister of Agrarian Affairs and Spatial Planning / Head of the National Land Agency Number 35 of 2016 concerning Acceleration of Complete Systematic Land Registration, Regulation of the Minister of Agrarian and Spatial Planning / Head of the National Land Agency Number 1 of 2017 concerning Amendments to Regulation of the Minister of Agrarian and Spatial Planning / Head of the National Land Agency Number 35 of 2016 concerning Acceleration of Complete Systematic Land Registration, Regulation of the Minister of Agrarian and Spatial Planning / Head of the National Land Agency Number 12 of 2017 concerning Acceleration of Complete Systematic Land Registration, Regulation of the Minister of Agrarian Affairs d Spatial Planning / Head of the National Land Agency Number 6 of 2018 concerning Complete Systematic Land Registration.

b. Secondary Legal Materials, materials that provide an explanation of Primary legal materials consisting of books discussing Land Registration and various Research and Scientific Journals that discuss Complete Systematic Land Registration (PTSL).

c. Tertiary Legal Materials, materials that provide guidance and explanation for primary and secondary legal materials. The tertiary legal materials used in this study are the Legal Dictionary and the Big Indonesian Dictionary (KBBI).

However, this normative legal research is also equipped with primary data to strengthen secondary data (Soekanto, 2014).

\section{Result and Discussion}

4.1 Systematic land registration arrangements in Indonesia

Land Registration is a series of activities carried out by the Government continuously and regularly, including the 
collection, processing, bookkeeping, and presentation and maintenance of physical data and juridical data, in the form of maps and lists, regarding land plots and apartment units. This registration includes the provision of proof of rights for land plots which already have owners and ownership rights to apartment units and certain rights that impose them. Meanwhile, complete systematic land registration, hereinafter abbreviated as PTSL, is the activity of first-time Land Registration which is carried out simultaneously for all objects of Land Registration throughout the territory of the Republic of Indonesia in one village area or other areas at the same level. This PTSL includes the collection of physical data and juridical data regarding one or more land registration objects for registration purposes (BPN, 2018).

Land registration is regulated in Article 19 of Law Number 5 of 1960 concerning Agrarian Principles (UUPA). Article 19 paragraph (1) of the UUPA states that: (1) To ensure legal certainty, the Government shall conduct land registration throughout the territory of the Republic of Indonesia, according to the provisions stipulated in a Government Regulation. Land registration carried out in Indonesia has objectives for the government, society and third parties. These objectives include: (a) providing legal certainty and legal protection to holders of land rights in the form of land title certificates, (b) providing information to interested parties, in order to easily obtain data, both physical data and juridical data that has been registered and open to the public, (c) the implementation of an orderly administration, both in terms of transfer, assignment, and elimination of rights to land plots and property rights of apartment units which must be registered at the local Land Office.

In the implementation of land registration, one of the land registration activities that are mostly carried out by the community is the land registration activity for the first time. This land registration activity for the first time is an activity carried out on land objects that have not been registered under Government Regulation (PP) Number 10 of 1961 concerning Land Registration and subsequently renewed by Government Regulation Number 24 of 1997 concerning Land Registration (PP No 24/1997). The first form of land registration activity is divided into two, namely: (a) 'systematic' land registration, which means that land registration is carried out for the first time simultaneously covering all land registration objects that have not been registered in the territory or part of a village; (b) 'sporadic' land registration, which means the first-time land registration concerning one or several land registration objects within the territory of a village individually or collectively.

Land registration for the first time has been implemented by the Government of Indonesia through the Complete Systematic Land Registration Program (PTSL). Systematic land registration is preferred because it speeds up data collection on land plots to be registered rather than through sporadic land registrations (Sumaria, 2010). The legal basis for PTSL is regulated in the Regulation of the Minister of Agrarian and Spatial Planning / Head of the National Land Agency (PMATR / KBPN) Number 35 of 2016 concerning the Acceleration of Complete Systematic Land Registration. Furthermore, the regulation was amended by PMATR / KBPN Number 1 of 2017 concerning Amendments to PMATR / KBPN Number 35 of 2016 concerning Acceleration of Complete Systematic Land Registration.

However, the aforementioned regulation was subsequently amended again by PMATR / KBPN Number 6 of 2018 concerning Complete Systematic Land Registration (PTSL). Regulatory changes to PTSL are amended considering that the previous PTSL regulations have not been able to run as expected, so that substance or material improvements are needed to adjust to the provisions of laws and regulations regarding land registration and other land provisions. The background of this program is because the government still finds a lot of land in Indonesia that is not yet certified or does not have a certificate. Land certification is something that must be done by the community to obtain legal certainty and authentic evidence of ownership of land plots as evidenced by land certificates (Devita, 2019).

The implementation of PTSL is currently carried out based on Presidential Instruction No. 2 of 2018 concerning Acceleration of Complete Systematic Land Registration, and PMATR / KBPN Number 6 of 2018 concerning Complete Systematic Land Registration, Joint Decree of the Minister of Agrarian Affairs and Spatial Planning / Head of the National Land Agency, Minister of Home Affairs, Minister of Villages, Disadvantaged Areas and Transmigration Number 25 / SKB / V / 2017, Number 590-3167A Year 2017, Number 34 Year 2017 concerning Financing for Systematic Land Registration Preparation. This PTSL is the first land registration activity carried out simultaneously for all land registration objects throughout the Republic of Indonesia in one village area. This activity aims to realize the provision of legal certainty and legal protection of community land rights, so that it is expected to reduce and prevent land disputes and conflicts. Legal certainty of land ownership can be realized by issuing land certificates (Santoso, 2010).

The principles used in implementing PTSL are simple, fast, smooth, safe, fair, equitable, open, and accountable. Basically, PTSL is carried out by the Government to improve the welfare and prosperity of the people and the 
country's economy. The implementation of this PTSL activity covers all objects of land registration throughout the territory of the Republic of Indonesia without exception, both land plots that do not yet have land rights or land plots that have rights in order to improve the quality of land registration data. This PTSL is carried out on land plots which already have boundary marks or which will be defined as boundary marks in the implementation of PTSL activities.

The implementation of PTSL activities as regulated in Article 4 paragraphs (4) and (5) PMATR / KBPN Number 6 of 2018 concerning Complete Systematic Land Registration is carried out in several stages as follows: (a) planning; (b) determination of location; (c) preparation; (d) establishment and determination of the PTSL adjudication committee and task force (SATGAS); (e) counseling; (f) physical data collection and juridical data collection; ( $\mathrm{g}$ ) research on juridical data to prove rights; $(\mathrm{h})$ announcement of physical data and juridical data and validation; (i) affirmation of conversion, recognition of rights, and assignment of rights; (j) bookkeeping of rights; (k) issuance of land title certificates; (1) documenting and submitting results of activities; and (m) reporting. The stages in this PTSL are carried out according to the object, subject, right base, and process as well as the financing of PTSL activities and the location will be determined by the Head of the local Land Office.

The implementation of PTSL activities as referred to in Article 4 paragraph (1) PMATR / KBPN Number 6 of 2018 concerning Complete Systematic Land Registration can be carried out through PTSL activities, or a combination of PTSL activities with other programs and / or activities, such as: (a) Certification Program Cross Sector; (b) Community Self-Help Mass Certification Program; (c) mass certification programs or activities for the redistribution of land objects of land reform, land consolidation, and transmigration; or (d) other mass certification programs or activities, or a combination of several / all activities as referred to in points a to point $d$ which are adjusted to the provisions of laws and regulations.

For efficiency and effectiveness of the implementation of PTSL activities, the Head of the Land Office will gradually determine the location for the distribution of PTSL targets which are concentrated in several villages and / or sub-districts in their working area. This location determination can be done in one village area or in stages in one stretch, provided that there is an PTSL budget that has been allocated in the APBN / APBD, PNBP, Corporate Social Responsibility (CSR) or other PTSL funding sources. In addition, prioritization is given to village locations where PRONA / PRODA activities, cross-sector, Mass Swadaya Certificate (SMS), CSR and / or other mass land registration programs, or it can also be based on the availability of legitimate funds in accordance with the provisions of laws and regulations where only for one village that is the object of PTSL. This is done by considering the ability of human resources / PTSL executing officers in each Land Office. In the event that the designated PTSL location consists of several villages, efforts are made to ensure that the villages that are the object of PTSL are located in a close area.

After the location of the PTSL was determined, the Head of the Land Office formed and appointed the PTSL Adjudication Committee and the Task Force, which was outlined in the form of a decision. The PTSL Adjudication Committee consists of: a. Chairman; b. Two Deputy Chairmen; c. Secretary for Land Affairs; e. The appointed local Village Head or Pamong Desa; and f. Members of the Land Office elements as needed.

The PTSL Adjudication Committee is assisted by the Physical Task Force, the Juridical Task Force and the Administrative Task Force. The Physical Task Force consists of elements of the Ministry's State Civil Servants, Non-Permanent Employees / Non-Civil Servant Government Employees of the Ministry, Licensed Cadastral Surveyors, Licensed Cadastral Surveyors Assistant and / or the Licensed Cadastre Surveyor Service Office (KJSKB) chaired by the Deputy Chairman of the physical sector of the PTSL Adjudication Committee. Furthermore, the Juridical Task Force consists of elements of the Ministry's State Civil Apparatus, Non-Permanent Employees / Government Employees Non-Civil Servants of the Ministry, Village / Sub-District Officials, RT / RW / Environment apparatuses, community organizations, Village Guidance NCO (BABINSA), Bhayangkara Guardians of Security and Community Order (BHABINKAMTIBMAS) and / or other community elements chaired by the Deputy Chairperson of the juridical field of the PTSL Adjudication Committee. While the Administration Task Force consists of elements of the Ministry's State Civil Apparatus, and can be assisted by Non-Permanent Employees / Government Employees of the Ministry of Non-Civil Servants, chaired by the Secretary of the PTSL Adjudication Committee. The activities in implementing PTSL in Indonesia can be detailed as follows:

\section{Extension Activities}

Activities in counseling about the existence of PTSL activities were carried out by the Head of the Land Office along with the PTSL Adjudication Committee, the Physical Task Force and the Juridical Task Force. The counseling was carried out by providing an explanation regarding: benefits for the community, 
government and the state for the results of the implementation of PTSL activities; stages and mechanisms of PTSL activities; determination and installation of boundary marks for each plot of land; juridical documents that need to be prepared; a schedule for measuring land parcels and collecting juridical data by the Physical Task Force and the Juridical Task Force; the final result of PTSL activities; financing provided by the Government and / or other legitimate sources through PTSL activities; legal consequences that occur if the obligations and responsibilities referred to in the points above are not fulfilled; the right to object to the results of adjudication announced during the announcement period; and costs and / or taxes that will be borne by PTSL activity participants. This counseling is addressed to the community, both those who have or do not have a certificate. Apart from that, it can also be applied to local governments, related agencies, law enforcers and / or community leaders.

\section{Physical Data Collection and Juridical Data Collection}

The collection, processing and maintenance of physical and juridical data on the determination of land rights and registration will use forms, maps and other lists as well as the entries in the Computerized Land Activities (KKP) application. In this case, the Head of the Land Office must ensure the conformity of data generated from Complete Systematic Land Registration activities with the electronic data in the KKP application. However, if there are other provisions in this Ministerial Regulation, then forms, maps, and other lists may be used in accordance with the provisions of the legislation with adjustments to the needs of Complete Systematic Land Registration activities. In order to optimize and simplify the implementation of PTSL activities: a. Physical data collection activities by the Physical Task Force and juridical data collection by the Juridical Task Force are carried out by 1 (one) team for each village where PTSL objects are located; $b$. physical data collection and identification of land plots can optimize third party and community participation; c. juridical data collection activities must be coordinated with the village / sub-district government, so that the juridical data on participants in PTSL activities can be collected collectively in a pre-determined place for each village or sub-district.

Physical data collection is carried out through the measurement and mapping of land plots carried out by the Physical Task Force by observing the provisions of laws and regulations. Measurement and mapping of land plots is carried out using survey and mapping technology, which consists of the terrestrial method, the photogrammetric method, the satellite method, or a combination of the three methods. In carrying out land plot measurements, the Physical Task Force must know data or information about each owner or party entitled to the land, at least in the form of a photocopy of KTP / Family Card / Certificate of residence from the authorized agency. The Physical Task Force in carrying out tasks can be assisted by a Licensed Cadastre Surveyor, KJSKB and / or a Company Legal Entity that is engaged in surveying and mapping geospatial information through procedures and financing. Standards, criteria, methods, procedures, and mechanisms for collecting, processing, presenting as well as maintaining physical data and documents are carried out in accordance with statutory provisions.

Furthermore, juridical data collection activities include collecting evidence regarding ownership or control of land, both written evidence, witness statements and / or statements concerned. This juridical data collection is carried out by the Juridical Task Force based on the provisions of laws and regulations. The Juridical Task Force in carrying out its duties can be assisted by the Juridical Data Collector through procedures and financing in which standards, criteria, methods, procedures, and mechanisms for collecting, processing, presenting and maintaining juridical data and documents are carried out in accordance with the provisions of laws and regulations. This juridical data collection is carried out through the collection and examination of the history of land ownership as outlined in the Treatise of Juridical Data Research.

\section{Juridical Data Research to Prove Rights}

In this PPTSL activity, the PTSL adjudication committee conducted juridical data research aimed at proving rights. If the proof of community land ownership is incomplete or absent, it can be completed and proven by a written statement regarding the physical ownership and / or control of the land plot with good intentions by the person concerned. This element of good intentions consists of the physical fact that the person or community controls, uses, utilizes and maintains the land from generation to generation for a certain period of time and / or obtains by means of not violating statutory regulations. This good intention is evidenced by the statement of the PTSL Adjudication applicant / participant stating that: a. there are no objections from other parties regarding the land that is owned or not in a dispute; b. does not include or does not constitute: 1) assets of the Government, Regional Government, or State-Owned Enterprise / Regional Owned Company; or 2) Forest Area.

Ownership statement letter is made provided that: a. witnessed by at least 2 (two) witnesses from the local 
environment who have no family relationship with the person concerned to the second degree, both in vertical and horizontal kinship, who state that the person concerned is indeed the owner and who controls the plot of land; and b. made based on information that is truthful and can be accounted for both civil and criminal. If in the future there is an element of untruth in his statement, it is not the responsibility of the PTSL Adjudication Committee. Statement of Physical Control over Plots of Land shall be made stamped and in accordance with the stipulated format.

\section{Announcement of Physical Data and Juridical Data and Their Endorsements}

After going through the stages of juridical data research to prove rights, the next step is to recapitulate the juridical data that has been contained in the Treatise of Juridical Data Research regarding land plots that have been mapped on land plot maps. The recitulation of this juridical data is carried out by entering it in the Juridical Data List and Physical Data on Land Plots. To fulfill the principle of publicity in proving land ownership, juridical data and physical data of land plots and land plot maps are announced for 14 (fourteen) calendar days at the PTSL Adjudication Committee Office and the Village or Sub-district Head Office. This is intended so that interested parties are given the opportunity to raise objections regarding the Announcement of Physical Data and Juridical Data. After the announcement period ends, the physical data and juridical data will be approved by the PTSL Adjudication Committee in the form of an Official Report on the Publication of Physical Data and Juridical Data.

If at the time of ratification of the physical data and juridical data there is still incomplete data or there are still objections that have not been resolved, then the physical data and juridical data will still be validated by providing a note to the Official Report on Legalization of Physical Data and Juridical Data regarding incomplete matters. and / or objections that have not been resolved. If there is a party who submits an objection, then a written notification is given to him to immediately file an objection to the Court. The intended objection will be recorded in the Objection / Rebuttal List to the Announcement of the Result of Research on Physical and Juridical Data.

\section{Completion of PTSL Program}

The complete systematic land registration activity is divided into 4 (four) clusters which include:

a. Cluster 1; Land plots whose physical data and juridical data meet the requirements to issue a Certificate of Land Rights. In such a case, the Chair of the PTSL Adjudication Committee can follow up by: a) confirming the conversion to Property Rights on behalf of the last right holder, for land plots whose written evidence is complete and whose written evidence is incomplete, but there are witness statements and statements which concerned, b) stipulates recognition / affirmation as Property Rights, for land plots whose proof of ownership does not exist but has been proven by the fact that physical control for 20 (twenty) years continuously including their predecessors, c) proposes a decision to grant rights, for a plot of land which is State land.

b. Cluster 2; Land plots whose physical data and juridical data meet the requirements to issue a Certificate of Land Rights but there are cases in court and / or disputes. In this case what can be done is: a) bookkeeping of rights by leaving the names of the right holders blank; and b) issuance of a certificate of Land Rights after a court decision is legally binding and the verdict states that one of the parties is entitled. In the event that the court decision is legally binding after the PTSL activity budget year ends, the Head of the Land Office will sign and issue a Certificate of Land Rights. The certificate is issued without replacing the land book that has been signed by the PTSL Adjudication Committee.

c. Cluster 3; Land plots whose physical data and juridical data cannot be recorded and a Certificate of Land Rights is issued, because the subject and / or object of their rights has not met certain requirements stipulated in a Ministerial Regulation. This cluster occurs in the following cases: a) the subject is a foreign citizen, BUMN / BUMD / BHMN, private legal entity, the subject is unknown, the subject is not willing to take part in PTSL activities, the subject is not willing to make a statement letter owed to the Acquisition Fee for Land and Building Rights ( BHTB) and / or income tax; b) PTSL objects are the land of the Dutch Ownership Implementation Committee (P3MB), the Dwikora Cabinet Presidium Regulation (Prk 5), Class III Houses that have not been paid for the lease, Nationalization Objects, Ulayat Land, Absent Land, and maximum excess land; c) PTSL objects are land objects for land reform, transmigration, and land consolidation whose certificates cannot be issued; d) the subject is not willing to make a statement of physical control over land plots, for PTSL objects which are former customary land; and e) object documents proving incomplete land ownership. However, the land in cluster 3 can be recorded in a Land Book and a Certificate of Land Rights is issued to the entitled parties, after: a) the requirements stipulated in accordance with the provisions of laws and regulations are met; b) requested by the entitled party with 
self-financing through the mechanism of Non-Tax State Revenue (PNBP). Furthermore, the signing of the issuance of the Certificate of Land Rights is carried out by the Head of the Land Office.

d. Cluster 4; Land plots whose object and subject have been registered and have land title certificates, either unmapped or mapped but not in accordance with field conditions or changes in physical data, must be mapped into a Complete Systematic Land Registration Map. This cluster is a program to develop a complete land plot mapping system within a single village administrative area.

\section{Issuance of Certificate}

If the property rights, building use rights, use rights, and waqf land that have been registered in the land ownership book meet the requirements for proof of their rights, a certificate of land rights can be issued the juridical data contained in the certificate includes restrictions; including restrictions on transfer of rights, restrictions on the use of land relating to coastlines or other restrictions. The old proof of rights document which forms the basis of bookkeeping will be cross-crossed with ink which will not make the existing writing / signs illegible. Or it can also be given an impression in the form of a stamp or writing, stating that the document has been used for the bookkeeping of rights, before being stored as a document. The signing of the certificate of land rights resulting from the implementation of PTSL activities is carried out by the Chair of the PTSL Adjudication Committee for and on behalf of the Head of the Land Office. The certificate of land rights is then handed over to the right holder or proxy, and the certificate of waqf is handed over to the nadzir. For PTSL locations where there is Land for Landreform Objects, Land Consolidation or objects of transmigration, a certificate of land rights can be issued with the following provisions: a) Land for Landreform Objects based on the spatial plan has been turned into non-agricultural land; b) the Land Consolidation object has been processed according to the stages according to the applicable provisions but rights have not been granted to the Land Consolidation participants; c) the object of transmigration has been granted Management Rights but has not been granted Land Ownership Rights to transmigration participants or the location of objects that were previously transmigration locations, but by the Minister for Disadvantaged Areas and Transmigration has been qualified as no longer a transmigration area.

Furthermore, if the recipient of a Land Title Certificate is not or unable to pay the BPHTB and / or there is still an arrears in the PPh payment by other parties on the land concerned, then the Land Title Certificate may still be issued. However, provided that the person concerned must make a statement that the BPHTB is owed. If the plot of land originates from the sale and purchase in the past and the present buyer does not have proof of payment of income tax from the seller in the past, then the person concerned must make a certificate of income tax payable. The contents of the indebted BPHTB statement letter and the indebted PPh statement must be contained in the Decree on Granting Land Rights and then recorded in the Land Book and Certificate as BPHTB owed from the land owner concerned or PPh owed by the land seller or concerned. The issuance of certificates to the recipients of this right can be carried out on the condition that the right recipients submit original proof of ownership papers; and the right recipient prepares an Outstanding BPHTB Statement and / or a Certificate of Income Tax payable. Furthermore, the Head of the Land Office must submit a list of outstanding BPHTB and / or income tax payable periodically within 3 (three) months to the local Regent / Mayor for BPHTB, to the local Pratama Tax Office for PPh, which contains participant identity (NIK), land location, land area, date and certificate number as well as the Sales Value of the Tax Object / tax certificate. The list of BPHTB and Outstanding Income Tax is based on the KKP application. The transfer of rights or changes to the Land Book and Land Title Certificate can only be done after the person concerned can prove that the BPHTB is owed and / or the PPh owed has been paid by the respective taxpayers.

If the proposed plot of land is joint property, which has not been divided / separated and requested by either party, either during marriage or divorce, it is still issued in the name of the husband and wife. If what is submitted is an undivided inheritance, it is still issued in the names of all heirs. If there is an administrative error in the issuance of a Certificate of Land Rights, repairs will be made based on the Official Report on Correction of Administrative Errors in accordance with the provisions of the legislation.

\section{Documentation and Submission of Activity Results}

In this stage, there is an obligation for the PTSL Adjudication Committee to collect, group, process and store PTSL data. These stages include: a) a juridical data document consisting of the identity of the right holder, the basis of the rights, an official report made by the committee, evidence of an announcement, an official report on the ratification of physical data and juridical data and a decision letter for granting rights; b) physical data documents: measurement data and calculation of measurement results, measuring drawings, land plot maps, and measuring letters; c) a list of registration of land and land rights; d) land books; e) Certificate of Land Rights; f) evidence of financial administration; and g) other administrative data. This data storage can 
be done in electronic form. The head of the PTSL Adjudication Committee hands over the results of the implementation of PTSL activities to the Head of the Land Office at the end of the PTSL activity and is accompanied by PTSL data. Submission of the results of the implementation of PTSL activities is made in the form of an Official Report on the Handover of files and documents from the results of PTSL activities signed by the Chair of the PTSL Adjudication Committee and the Head of the Land Office. The results of PTSL activities are stored, documented and archived by the Head of the Land Office. The results of PTSL activities were also conveyed to the One Map Policy Acceleration Team to strengthen the One Map Policy database. Reporting on the implementation of PTSL activities is carried out when: problems occur in the implementation of PTSL activities; and after the PTSL was completed. Reporting when problems occur in the implementation of PTSL activities is carried out by the Chair of the PTSL Adjudication Committee to the Head of the Land Office with copies to the Director General of Legal Relations and the Head of the Regional Office of BPN. Reporting when PTSL is completed is carried out in stages and periodically from the Head of the Land Office, to the Head of the Regional Office of BPN and the Minister

\subsection{Barriers to Systematic Implementation of Land Registration}

Systematic land registration according to Article 1 number PP Number 24 of 1997, it is stipulated that in carrying out a systematic registration, the Head of the Land Office assisted by the Adjudication Committee is formed by the State Minister for Agrarian Affairs / Head of the National Land Agency or a designated official. Regarding the formation of the adjudication committee and the composition of duties and authorities will be further regulated. Adjudication is an activity carried out in the context of the process of registering land for the first time, including the collection and determination of the correctness of physical data and juridical data regarding one or several land registration objects for the purpose of registration. Complete Systematic Land Registration is carried out in the context of realizing the presence of the State in the land sector by guaranteeing legal certainty of land rights. This is as mandated in article 19 of Law Number 5 of 1960 concerning Basic Agrarian Regulations. The government is obliged to carry out land registration throughout the territory of the Republic of Indonesia.

The strategy of the Ministry of Agrarian and Spatial Planning to accelerate land registration is carried out through the Accelerated Implementation of Complete Systematic Land Registration program as regulated in the Regulation of the Minister of Agrarian and Spatial Planning / Head of the National Land Agency Number 35 of 2016 in conjunction with Regulation of the Minister of Agrarian Affairs and Spatial Planning / Head of BPN Number 1 Year 2017 as amended by Regulation of the Minister of Agrarian Affairs and Spatial Planning Number 12 of 2017 concerning Acceleration of Complete Systematic Land Registration. In this case, the involvement of the Licensed Cadastral Surveyor cannot be implemented optimally and is still using or guided by the Regulation of the Head of the National Land Agency Number 9 of 2013 concerning Licensed Cadastral Surveyors. Thus, it does not fully refer to the Regulation of the Minister of State for Agrarian Affairs Number 33 of 2016.

Implementation of Complete Systematic Land Registration will not be successful without support from other agencies / sectors. Local government support is something that must be provided, therefore in terms of completeness of the PTSL files, it is issued by another agency. The formal truth and material for the rights that are submitted for lands that have not been administered in the ledger book, for example, land which is a product of the Village Government. Based on the research results, it turns out that not all local governments and communities support the implementation of the PTSL program. PTSL activities really demand a guarantee of legal certainty. One of the important issues related to legal certainty is the principle of publicity which has different arrangements between government regulations and ministerial regulations. To fulfill the principle of publicity in proving land ownership, the announcement of physical data and juridical data is carried out for 14 (fourteen) calendar days (Article 24 of Regulation of ATR / Ka. BPN No. 6 of 2018).

The aforementioned provisions are in fact different from Article 26 PP No.24 of 1997 concerning Land Registration which requires 30 days and Article 63 PMNA/ Ka. BPN No. 3 of 1997 concerning Provisions for the Implementation of Government Regulation No. 24 of 1997 concerning Land Registration. Different regulations on the publicity principle provide room for potential disputes in the future, because in principle, lower regulations should not conflict with higher regulations. According to Soeprapto (2010), based on the theory of legal norms level put forward by Hans Kelsen, namely stufentheorie, which states that legal norms are tiered and layered in a hierarchy, where a lower norm applies, originates and is based on higher norm. Higher norms apply, originate and be based on even higher norms. And so on until a norm called the basic norm (grundnorm). Sitorus (2017) also states that: asynchrony invalidates the lower rule of law. However, in the practice of state administration, the asynchrony of the rules does not automatically invalidate the lower rules before the lower rules are canceled by 
the court which is authorized to conduct a judicial review. Therefore, the Ministerial Regulation on PTSL remains in effect before a judicial review decision is made by the Supreme Court.

In the government's perspective, the time for the announcement of physical data and juridical data for 14 calendar days is still too long, because this opens the possibility of shortening the announcement when referring to Presidential Instruction No. 2 of 2018 concerning the Acceleration of Complete Land Registration which basically orders the Ministry of ATR / BPN to revise / amend Permen ATR / Ka. BPN No. 12 of 2017 relating to: a). The categories of K1 to K4 are revised into 3 clusters, b) Making regulations and taking steps to accelerate PTSL in the process of proving and / or controlling land, c) making / preparing / revising regulations governing the time frame for announcing physical and juridical data to accelerate the completion of PTSL, d) deliver PTSL output to strengthen the one map policy database, e) conduct evaluation and monitoring and report to the president periodically. However, it turns out that the ATR / Ka. BPN No. 6 of 2018 as a result of the revision of the Permen ATR / Ka. BPN No. 12 of 2017, there are still no substantive changes as requested in Presidential Instruction No. 2 of 2018. Because the changes made are only at the normative level. Still using the K1 to K4 cluster system (Article 25); The period for the announcement of physical data and juridical data is still the same 14 calendar days (Article 24); The steps for resolving the acceleration of PTSL are only accommodated in Chapter V separately, in substance there is no change in the Permen ATR / Ka. BPN No. 12 of 2017. Thus, the PTSL output which is regulated too vaguely is only one paragraph in Article 38 paragraph (3) which only states that the results of PTSL activities are also conveyed to the One Map Policy Acceleration Team to strengthen the One Map Policy database.

The contradiction in an activity in placing the boundaries of land parcels based on the agreement of the parties having an interest in land registration is said to be to fulfill the principle of Contradictoire Delimitatie. Delimitation contradiction is a norm used in Land Registration by requiring land rights holders to pay attention to the placement, determination and maintenance of land boundaries based on the agreement of the interested parties. In this case, it is the owner of the land bordering the land he owns. If the owners of bordering land do not get an agreement on the actual location of a boundary even though mediation has been carried out, then the boundary determination is carried out by a court decision (Articles 17, 18, 19 of Government Regulation No. 24 of 1997). Therefore, the consent and presence of the owner of the adjacent land is an obligation in land registration.

In practice, the application of the delimitation contradictory principle has encountered many difficulties in the field, both in the routine implementation of land registration as usual and in the PTSL program. Several obstacles that cause difficulties and cause the contradictory principle of delimitation cannot be implemented properly, including: a) land rights holders do not maintain good land plot boundaries which have become their obligations so that it often causes overlapping of land plot boundaries, b) parties are not present at the time to determine the land boundary, because the land owner is busy and or it is difficult to find the land owner because of absentee land ownership; c) there are land boundary disputes, family or neighbor disputes and disputes that have entered the court's domain. These problems become obstacles to the measurement process. Socialization in the form of counseling to the community regarding the importance of placing, determining and maintaining land boundaries in the measurement process is the responsibility of the land owner, not the authority of the Measuring Officer. The authority of the measuring officer is to measure the boundary markings that have been installed by the right holder and the owner of the adjacent land, not to put up a boundary mark. It is the obligation of the land owner to maintain land boundaries such as giving a stake as land boundary, no longer having to be installed and owned by the BPN.

To solve this problem, Ratmono (2007) conveyed the idea that: mass movements put up land plots boundary marks at locations to be determined, by means of the participation of all land plot owners by putting up land plot boundary signs. Plot boundary markings are prepared by assigned community groups, for example, Karang Taruna according to directions from the local land office. The factor of determining the location and boundaries of each land plot cannot be ignored, because in fact there are quite a number of land disputes arising as a result of the wrong location and boundaries of land plots, and even quite a number of land boundary disputes are brought to court.

In the implementation of PTSL, the issue of proving rights as regulated in Article 22 of the Minister / Ka Regulation. BPN No. 6 of 2018 is often an obstacle. The problem is related to a written statement regarding the physical ownership and / or control of land parcels with good intentions, but the evidence of land ownership is incomplete or absent. The provisions of Article 22 require a written statement regarding physical control over land parcels and with good intentions. The statement of physical control over land plots must be witnessed by at least 2 (two) witnesses from the local environment and have no family relationship and can be accounted for both civil and criminal. If in the future there is an element of untruth in his statement, then this is not the responsibility of the PTSL Adjudication Committee. Based on these provisions, it can be interpreted as follows: (a) Physical control over the land plot in question is for 20 (twenty) years or more consecutively and not less than 20 years; (b) A statement of physical control over land plots must be witnessed by at least 2 (two) witnesses, who are generally 
known to the RT, RW and local village; (c) If there is an element of untruthfulness the statement letter is not the responsibility of the PTSL Adjudication Committee.

In PTSL activities, the statement of physical control of land plots often becomes an obstacle because it requires registration obligations, procedures, prohibitions, supervision, reporting, and sanctions in this case, which is intended to create orderly land administration in the village. This is done to minimize the occurrence of land dispute cases, so that the Statement of Physical Mastery of Land as formal evidence of control over land with good intentions is proven by the statement of the applicant / participant of the PTSL Adjudication which states: a) there are no objections from other parties regarding the land they own or not in a state of dispute; b). not included or not an asset of the Government, Regional Government, or State-Owned Company / Regional Owned Company; or Forest Area (Article 22).

Basically, good intentions are interpreted as honesty. Honesty of rights holders in the acquisition of their land, honesty in fulfilling predetermined conditions. However, to identify good intentions is not an easy problem, because it has an abstract meaning that gives rise to different meanings. Good intentions based on Article 22 of the Ministerial Regulation / Ka. BPN No. 6 of 2018 is honesty in physical control of the land and honest in fulfilling predetermined conditions. The measure used to determine goodwill by the Adjudication Committee can be in the form of careful estimates that the applicant has fulfilled the prescribed administrative requirements.

\section{Conclusion}

Based on the findings and discussions that have been carried out, it can be concluded that the implementation of systematic land registration in Indonesia has been carried out as regulated in PMATR / Ka.BPN No. 6 of 2018 concerning Complete Systematic Land Registration. However, there are slight differences in the implementation of PTSL in several provisions in PP No. 24/1997 concerning Land Registration, especially those related to the deferral of payment of transitional taxes (BPHTB and / or PPh) and the announcement period. However, this land registration activity still provides legal certainty to the community in controlling land originating from PTSL activities. In addition, the main objective of implementing PTSL is for the Government to have a single map of land in Indonesia. Furthermore, the obstacles in implementing PTSL in Indonesia are generally caused by the lack of adequate human resources, the lack of facilities and infrastructure to support the implementation of PTSL in the regions, the lack of full support from the community for PTSL activities, and the large tax costs on land that owned by the community.

\section{References}

Harsono, Boedi, 2003, Hukum Agraria Indonesia: Sejarah Pembentukan UUPA Isi dan Pelaksanaannya, Ed. Revisi, Cet.8. Djambatan, Jakarta.

https://kominfo.go.id/content/detail/12924/program-ptsl-pastikan-penyelesaian-sertifikasi-lahan-akan-sesuaitarget/0/artikel_gpr, diakses 5 September 2020.

Ihsanuddin. "Jokowi: Prona Sudah 35 Tahun, baru 44 Persen Tanah Warga Bersertifikat", https://nasional.kompas.com/read/2016/10/16/12474581/jokowi.prona.sudah.35.tahun.baru.44.persen.tan ah.warga.bersertifikat, diakses 18 Agustus 2020.

Instruksi Presiden Nomor 2 Tahun 2018 Tentang Percepatan Pendaftaran Tanah Sistematis Lengkap di Seluruh Wilayah Republik Indonesia,

Irma Devita, Pendaftaran Tanah Sistematis Lengkap (PTSL), https:// irmadevita.com/2019/ pendaftarantanahsistematis-lengkap-ptsl, diakses 3 September 2020.

Isdiana Kusuma Ayu, "Kepastian Hukum Penguasaan Tanah Melalui Pendaftaran Tanah Sistematis Lengkap di Kota Batu”, Mimbar Hukum, Volume 31, Nomor 3, Oktober 2019.

Peraturan Menteri Agraria dan Tata Ruang/Kepala Badan Pertanahan Nasional Nomor 35 Tahun 2016 Tentang Percepatan Pelaksanaan Pendaftaran Tanah Sistematis Lengkap

Peraturan Menteri Agraria dan Tata Ruang/Kepala Badan Pertanahan Nasional Nomor 1 Tahun 2017 Tentang Perubahan Atas Peraturan Menteri Agraria dan Tata Ruang/Kepala Badan Pertanahan Nasional Nomor 35 Tahun 2016 Tentang Percepatan Pelaksanaan Pendaftaran Tanah Sistematis Lengkap

Peraturan Menteri Agraria dan Tata Ruang/Kepala Badan Pertanahan Nasional Nomor 12 Tahun 2017 tentang Percepatan Pendaftaran Tanah Sistematis Lengkap

Peraturan Menteri Agraria dan Tata Ruang/Kepala Badan Pertanahan Nasional Republik Indonesia Nomor 6 Tahun 2018 tentang Pendaftaran Tanah Sistematis Lengkap

Peraturan Menteri Negara Agraria Nomor 3 Tahun1997 tentang Pelaksanaan PP 24 Tahun 1997 tentang Pendaftaran Tanah 
Peraturan Pemerintah Nomor 24 Tahun 1997 tentang Pendaftaran Tanah

Purbaya, AA 2017, Lewat Sambungan Video, Jokowi Bagikan Sertipikat Tanah di 5 Daerah. https://news.detik.com/berita/d-3783024/lewat-sambunganvideo jokowi-bagikan-sertipikat tanah-di-5daerah, diakses tanggal 5 September 2020.

Ratmono 2007, "Pelibatan masyarakat dan stakeholder terkait dalam percepatan pelaksanaan

Pendaftaran Tanah Sistematis Lengkap (PTSL)”, Prosiding seminar nasional percepatan pendaftaran tanah di indonesia: Tantangan pelaksanaan PTSL dan respon solusinya, Sekolah Tinggi Pertanahan Nasional (STPN), Yogyakarta.

Sangsun,Florianus SP, 2007, Tata Cara Mengurus Sertifikat Tanah, Visi Media, Jakarta.

Sitorus, 2017. 'Faktor-Faktor Yang Mempengaruhi Keberhasilan Program Pendaftaran Tanah Dan Peran Perguruan Tinggi Dalam Mengakselerasi PTSL', Prosiding Seminar Nasional Pertanahan, STPN-Press, Yogyakarta.

Soekanto, Soerjono,2014, Pengantar Penelitian Hukum, Universitas Indonesia, Jakarta.

Soeprapto, 2010, Ilmu Perundang-undangan: Jenis, Fungsi, dan Materi Muatan, Kanisius, Yogyakarta.

Sumarja, FX., 2010, Hukum Pendaftaran Tanah, Universitas Lampung, Bandar Lampung.

Tehupeiory, Aartje, 2012, Pentingnya Pendaftaran Tanah di Indonesia, Raih Asa Sukses, Jakarta.

Undang-Undang Nomor 5 Tahun 1960 tentang Peraturan Dasar Pokok-Pokok Agraria

Urip Santoso, 2010, Pendaftaran dan Peralihan Hak atas Tanah, Prenada Media Group, Jakarta. 